\title{
燃料油タンク底板外面の腐食と交流インピーダンス特性
}

\author{
浅 利 満 頼*, 須 藤 皓**, 水流 徹*, 春山志郎* \\ *東京工業大学工学部 \\ **東北電力株式会社総合研究所
}

\section{AC Impedance Characteristics and Corrosion of Outside of Fuel Tank Bottom}

\author{
Mitsuyori Asari*, Shiroshi Sudoh**, Tooru Tsuru* \\ and Shiro Haruyama* \\ * Faculty of Engineering, Tokyo Institute of Technology \\ **General Research and Development Institute, \\ Tohoku Electric Power Co. Ltd.
}

\begin{abstract}
Impedance characteristics of corrosion at asphalt-sand/steel interface were studied on laboratory scale tests and model tanks of $2 \mathrm{~m}$ in diameter. The equivalent circuit and impedance were interpreted in a similar manner to the under film corrosion of coated steels. Degradation of asphalt-sand layer was evaluated from decrement of film resistance $R_{\mathrm{f}}$, and the corrosion rate was estimated qualitatively from the impedance $R_{\text {cor }}$ measured at the lowest frequency range around or less than $10 \mathrm{mHz}$. It was confirmed that the main factors to increase the corrosion rate of tank bottom were penetration of water precipitated and oxygen into the asphalt-sand/bottom plate interface. The two frequencies impedance method, proposed previously by the authours, can be applied as monitoring corrosion of fuel tanks, being supported by these impedance characteristics.
\end{abstract}

\section{1. 緒言}

国内の燃料油（原油・重油等）の貯蔵タンクは，大型 化と増設の時期を経て, 現在, 保守・点検の時期になり つつあるいえる。これらタンクの大型化に伴い, 腐 食・破損等による内容物の漏洩事故は, 経済的にも社会 的にも重大な損失と深刻な影響をもたらすことから，腐 食事故の防止法と腐食状況の監視法に大きな社会的関心 が持たれている1) 3)。

タンク (特に大型タンク) 底板外側の腐食に対しては, タンクをオイル・サンド，アスファルト・サンド等の防 食基礎マット上に設置し, 地下水や雨水の侵入を防止す る工法が推奖されているが4)，その効果については十分 に検討されているとはいえない。また，開放点検の際に タンク内側からの超音波厚み計による肉厚測定が一般的 に行われているが, 点検から次の点検まで 5 年または 10

* 个152 東京都目黒区大岡山 2-12-1 (2-12-1 O-okayama, Meguro-ku, Tokyo, 152 Japan)

** 干980 仙台市中山 7-2-1 (7-2-1, Nakayama, Sendai, 980 Japan)
年，時にはそれ以上の期間があり，この間の腐食速度の 変動を推定・追跡することは困難である。

著者らはこれまで，水溶液中に持ける金属材料の腐食 速度を交流インピーダンス法により測定することを試 み ${ }^{5)}$, その理論的解析に基づいて交流法腐食モニターを 開発し実用化をはかってきだ)。本報は，モデル・タン ク及び実験室試験により，アスファルト・サンドと接し た鋼板の腐食に関する交流インピーダンスを測定し腐食 状況との対応を調べること，及びその結果から交流法腐 食モニターの適用性の可否を検討し, 基礎的データを得 ることを目的とした。な执，腐食モニターによる結果は 一部を別に報告しだ)。

\section{2. 実験方法}

モデル・タンク 直径 $2 \mathrm{~m}$, 高さ $2 \mathrm{~m}$ のモデル・タ ンク 3 基を火力発電所構内（新潟市）に設置した。これ らのタンクは, Fig. 1(a) に示すように, 防水コンクリー 卜基礎，海水を含む砂，さらにその上に施工されたアス ファルト・サシド基礎マット層上に設置し， $60^{\circ} \mathrm{C}$ に加 

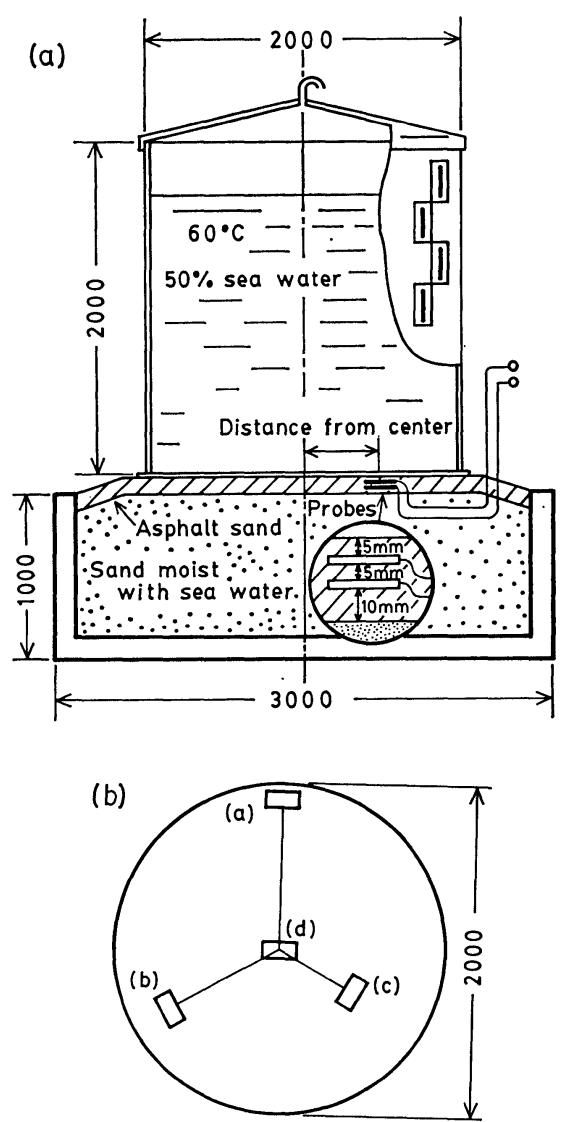
(a) $900 \mathrm{~mm}$
(b) $750 \mathrm{~mm}$
(c) $500 \mathrm{~mm}$
(d) $0 \mathrm{~mm}$

Distance from cente

Fig. 1 Scheme of the model tank and probes buried in asphalt-sand mat (a), and locations of the probes (b).

熱された海水を満たした。後に触れるように底板周辺部 の防水工事（雨仕舞）は行っていない。Fig. 1(a), (b) に 示すように，底板と同材質〈SS 41〉の鋼板（表面積 400 $\left.\mathrm{cm}^{2}\right) 2$ 枚を交流インピーダンス測定用電極（プローブ） としてアスファルト・サンド中に埋め込んだ。

実験室試験 SS 41 鋼板の片面に約 $9 \mathrm{~mm}$ のアスファ ルト・サンド層を付着させ，裏面と端面をシリコンゴム 系シーラントで覆った試料 2 枚 1 組を模擬海水を含む砂 中に埋めた。試料面積は $28 \mathrm{~cm}^{2}$ で, 乾燥を防ぐために 適宜蒸留水で湿らせた。

測定方法 インピーダンス測定は, エレクトロメータ と周波数応答解析装置 (NF 回路, S 5720) を用いた 2 電 極式 ${ }^{8)}$ にり，印加電圧 $50 \mathrm{mV}$, 周波数範囲 $10 \mathrm{mHz} \sim$
$100 \mathrm{kHz}$ で行った。

\section{3. 実験結果}

\section{1 モデル・タンクにおけるインピーダンス特性}

モデル・タンクの各位置に㧤いて測定されたインピー ダンス特性の経時変化を Fig. 2 に示す。全体にインピ ーダンスがかなり大きく，また野外での測定であったこ とから, 特に $10 \sim 100 \mathrm{~Hz}$ 付近に和いて雑音によるばら つきが目立つが，図中の破線で示した特性であると考觉 ることができる。

図よりプローブ電極の埋め込み位置によってインピー ダンス特性が大きく異なることがわかる。すなわち, タ ンク周辺部に最も近い場合には (Fig. 2 (a)) 初期（埋設 15 日後) のインピーダンスも低く, 長期間経過後は数 $\mathrm{k} \Omega$ にまで低下している。一方, 中心部に近いプローブ (Fig. 2(b), (c)) では初期に $100 \mathrm{~m} \Omega$ を越光, 時間の経過 によるインピーダンスの低下もそれ程大きくない。た だ，中心に置かれたもの (Fig. 2-d) では, 48 日, 110 日経過後のインピーダンスが他よりやや小さくなってい る。また，いずれのインピーダンス特性も，低周波数で 抵抗性を示す水平な部分と高周波数で容量性を示す右下 がりの直線とからなる単純な形であるといえ, 通常の腐 食系や電気化学系に見られる高周波数での溶液抵抗に対 応する水平部は測定されていない。

\section{2 インピーダンスと腐食状況との相関}

モデル・タンクを設置し 320 日経過後, タンク内面及 び底板の腐食状況を目視・写真撮影・超音波厚み計によ り点検しだ。Fig. 3 は底板の腐食程度のスケッチとプロ ーブ電極の埋設位置を示す。

腐食は周縁部ほど激しく，また底板溶接当て板（図中 の中心部を通る 2 本の直線）に添って腐食域が侵入して いるが，一部には黒皮が付着したままでほとんど腐食が 認められない場所もあった。なお, 超音波厚み計による 測定では，周縁部で腐食による減肉が認められたもの の，他の領域では測定誤差範囲の減肉であった。

インピーダンス特性との対応では, 外周部に近い $\mathrm{a} に$ お䚾周波数でのインピーダンスが最も低く，腐食の 程度が小さい b, d でのインピーダンズは腐食の最も少 なかったcよりやや低い值となっている。測定された最 も低い周波数でのインピーダンスが腐食速度の指標を与 えるものと考えれば，この結果はかなりよい対応関係を 示しているといえる。ただ，本実験においては試験期間 が短く, 腐食量が小さかったことから,インピーダンス ・データと定量的な対応はつけられなかった。

\section{3 実験室試験におけるインピーダンス特性}

海水を含む砂中に埋めたアスファルト・サンド付着試 料のインピーダンス特性の経時変化を Fig. 4 に示す。 

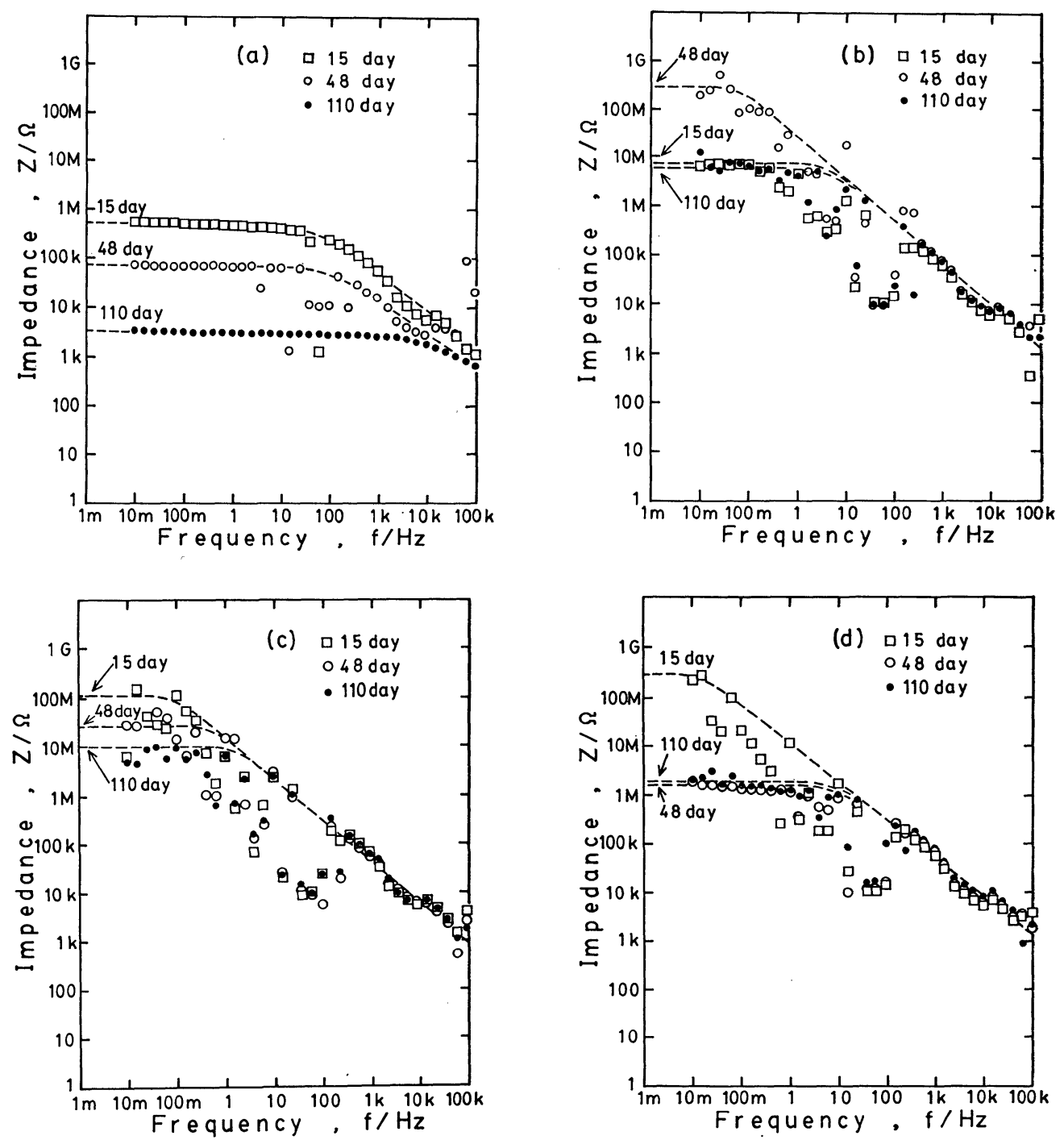

Fig. 2 Change in Bode plots of the probes. Impedance characteristics depend upon the distance from the center of tank.

なお。, $10 \mathrm{kHz}$ 以上の高周波数側では位相差が正となっ たが，標準抵抗の測定值により補正したものを示した*。

砂に海水を注入した直後はかなり大きなインピーダン スを示し，低周波数でも顕著な位相差の低下は見られな い。しかし， 20 時間経過後には低周波数で約 1 桁のイ ンピーダンス低下が, 115 時間後にはさらに 1 桁以上の

* 高周波数ではセルインピーダンスが低下し微小交流 電圧となるため, エレクトロメータにより位相が回 転し正の位相差となった。補正では, 測定されたイ ンピーダンスと汪注等しい純抵抗 (金属皮膜抵抗)を セルと置換した回路で測定し, 得られた位相差（多 くの場合正であった）をその周波数・インピーダン スに打ける測定装置系の位相回転量と仮定し差し引 いた。
低下が見られる。さらに 3.5 カ月後には 1 桁前後のイン ピーダンス低下が示されているが, 浸漬開始後 2 力月〜 8 カ月の間汇は実質的なインピーダンス特性の変化は見 られなかった。

一方位相差については，浸漬開始直後から 20 時間前 後までは, 低周波数側でやや小さくなるものの周波数依 存性はそれ程明瞭ではない。ところがその後の変化で は, $1 \sim 10 \mathrm{kHz}$ 付近での位相差が徐々に小さくなるとと もに, $0.1 \sim 10 \mathrm{~Hz}$ 付近での位相差が徐々に大きくなっ ている。特に後者は時間とともに極小が明瞭になり, そ の周波数も低周波数側へ移行するのがわかる。

以上の実験室試験の結果は, モデル・タンクに打る 4 カ所の測定点の中では Fig. 2 (a) に示されたモデル・ 

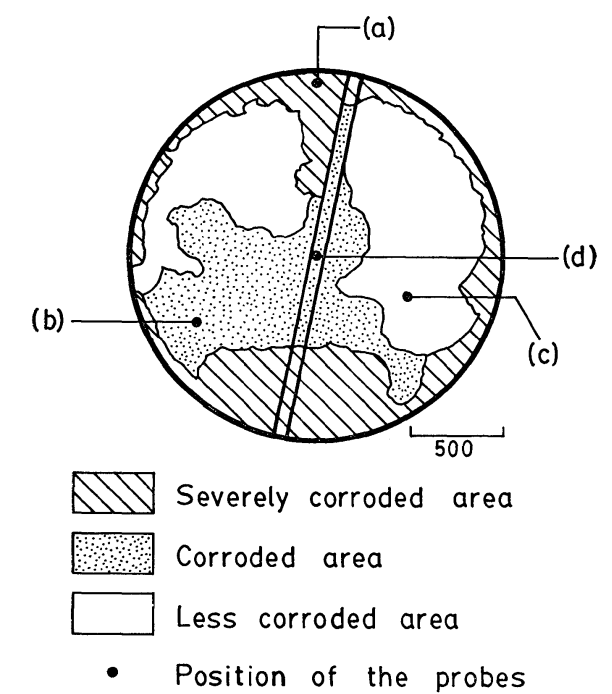

Fig. 3 Appearance of the outside of the tank bottom after 320 days exposure.

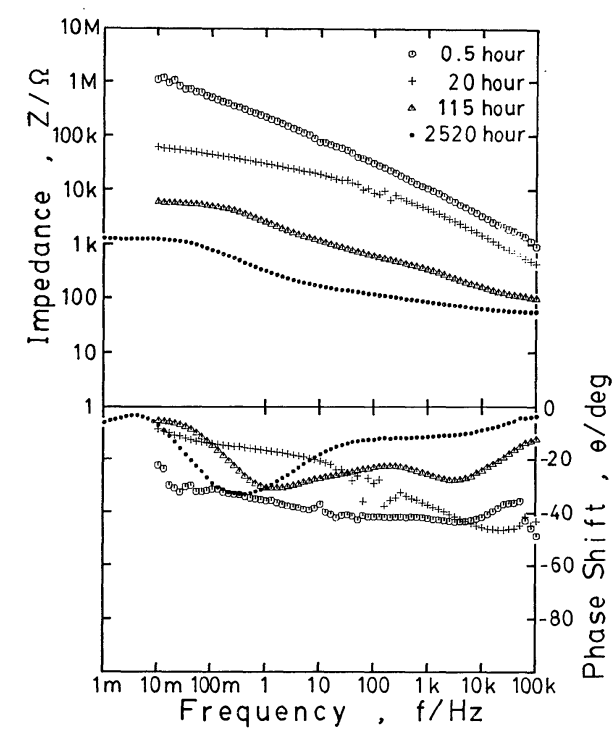

Fig. 4 Change in Bode plots of a steel coated with thick asphalt-sand layer and buried in sand moist with sea water.

タンク実験のタンク最外縁部に埋設されたプローブのイ ンピーダンス特性に類似している。すなわち，時間の経 過とともに低周波数域でインピーダンスが著しく低下す ること，及び Fig. 4 の結果程顕著ではないが $100 \mathrm{~Hz}$ 前 後以下で徐々にインピーダンスが増加する点である。こ れは後でも述べるように, 実験室試験もタンク外縁 部 も，ともに水及び空気の供給が十分で腐食反応が起こり やすいことと対応している。

\section{4. 考察}

\section{1 インピーダンス特性と等価回路}

実験室に蛙忊る電極系は，単純にはアスファルト・サ ンドによる塗装膜とみなすことができる。著者ら゙)及び 多くの研究者は, 腐食が進行している塗膜系に対し Fig. 5 に示す等価回路を提案している。図に颃いて， $C_{\mathrm{f}}$ は塗膜（アスファルト・サンド層）の容量， $R_{\mathrm{f}}$ はその 層の直流抵抗， $C_{\mathrm{d} 1}$ と $R_{\mathrm{cor}}$ は塗膜/金属界面における二 重層容量と腐食反応抵抗， $R_{\mathrm{so} 1}$ はアスファルト層外部 の溶液抵抗である。

本報に招いては，通常の塗膜に比較して $C_{\mathrm{f}}$ と $R_{\mathrm{f}}$ が 極端に小さく， $R_{\mathrm{sol} 1}$ はかなり大きいと考学られる。特 に $R_{\mathrm{f}}$ については, アスファルト・サンドの気孔率が高 く, 水分の多い環境では油分の流出もあり, 抵抗值が予 想以上に低下する。

実験室におけるインピーダンス測定結果と等価回路の 関係は次のように理解することができる。

浸漬 (3\% 塩食水注入) 初期には, アスファルト・サ ソド層への水分浸透量も少ないため $R_{\mathrm{f}}, R_{\mathrm{cor}}$ ともに極 めて大きく，インピーダンスは泳ほ $C_{\mathrm{f}}$ の特性をそのま ま示す。ここでインピーダンス特性の勾配がー1/2 に近 く, 位相差もほぼ $45^{\circ}$ であることから, 拡散 (Warburg) インピーダンスの奇与とする説明もあり得るが，浸漬直 後の測定からこの現象が観察されて括り (Fig. 4), 理論 的な勾配-1（または位相差 900）からのずれはアスファ ルト・サンド層に含まれる種々の成分による誘電損失と 考えるのが妥当であろう。

時間の経過とともにアスファルト・サンド層への水分 の浸透が進み，この層の抵抗 $R_{\mathrm{f}}$ が低下し，金属との界 面に形成される二重層容量が増加し, 腐食反応抵抗 $R_{\mathrm{cor}}$ が低下する。Fig. 4 において $10 \mathrm{~Hz} \sim 1 \mathrm{kHz}$ 付近に見 られるほぼ平坦なインピーダンスはこの $R_{\mathrm{f}}$ に対応し， その低下に従って位相差も小さくなる。これらは，アス ファルト・サンド中への水分の浸透, すなわち劣化の程

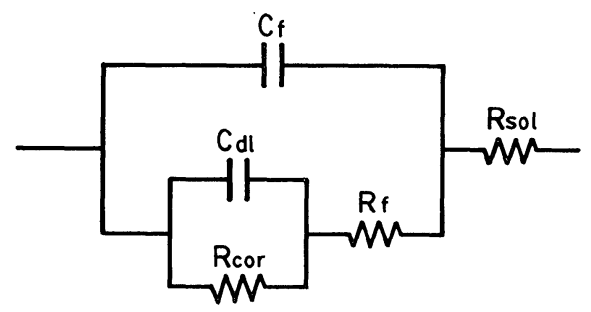

Fig. 5 Equivalent circuit of coated steel degraded in solution. $R_{\mathrm{f}}$ and $C_{\mathrm{f}}$; resistance and capacitance of coated film, $R_{\text {cor }}$ and $C_{\mathrm{d} 1}$; corrosion resistance and double layer capacitance at the metal/solution interface under the film. 
度が $R_{\mathrm{f}}$ と強い相関を持つことを示している。さらに, アスファルト層の外にある抵抗（溶液抵抗 $R_{\mathrm{sol}}$ ） は時間 の経過によっても変化しないと考兄られるのに対して, Fig. 4 の $100 \mathrm{kHz}$ に和けるインピーダンスが変化して いることは， $R_{\mathrm{sol}}$ がさらに高い周波数（例觉ば $1 \mathrm{MHz}$ 以上) で測定される可能性を示している。

一方, 界面のインピーダンス $\left(C_{\mathrm{d} 1}\right.$ と $\left.R_{\mathrm{cor}}\right)$ は $0.1 \sim$ $1 \mathrm{~Hz}$ 付近に見られるインピーダンスの増加と位相差の 極小に対応して括り, 腐食反応の進行やアスファルト成 分の溶出による金属/溶液界面積の増加（特に $C_{\mathrm{d} 1}$ の増 加）に伴って，その極小が顕著となり極小を示す周波数 も低下寸る。

Fig. 5 に示された等価回路に従えば， $R_{\text {cor }}$ は最も低い 周波数でのインピーダンスに対応するはずである。実験 室試験の結果からは $R_{\text {cor }}$ と実際の腐食量との対応つけ ることはできなかったが，モデル・タンクによる結果 (Fig. 2 と 3) との対応から， $R_{\text {cor }}$ と腐食速度との相関 は明らかである。な拈, Fig. 5 は実験室試験に対する等 価回路であるが，モデル・タンクのプローブ対につい ても， $R_{\mathrm{so1}}=0$ (アスファルト層の外側の抵抗が含まれ ない，すなわち両試料極のアスファルト層が直接接触し ている）とすれば，同様の等価回路を考えることができ る。

以上のことから，プローブを使用した交流インピーダ ンスの測定によって， $R_{\mathrm{f}}$ の低下の程度からアスファル ト・サンド層の劣化程度を, $R_{\mathrm{cor}}$ からタンク底板/アス ファルト・サンド界面での腐食速度を，それぞれ評価す ることが可能であることが示された。また，著者らの開 発した交流法腐食モニター6)は, 原理的に $R_{\text {cor }}$ と $R_{\mathrm{f}}$ の 双方を測定できることから，このモ二ターによる腐食速 度の監視が可能であることがわかる。

\section{2 タンク底板の腐食機構}

Fig. 3 に示されたタンク底板の腐食状況の分布につい て簡単に検討する。

先にも述べたように，腐食はタンク周縁部で激しく， 中心部ではほとんぞ腐食の見られない部分るあった。特 に注目されるのは，2 枚の底板を付き合わせ溶接した当 て板に沿って腐食速度の大きな領域が中心部まで広がっ ていることである。

本報の試験では, タンクをアスファルト・サンド上に 設置後, 周縁部を防水シールする等のいわゆる雨仕舞い 処理を行っていない。そのため外周の一部では基礎と底 板との間にすき間が生じている場所も観察された。

さらに, 溶接部では底板と同材質, 同厚 $(4 \mathrm{~mm})$ の当 て板が直径方向に走って打り, 底板と当て板によって生 じるコーナーには汪とんどアスファルト・サンドは付着 していなかった。これらのことから, 底板周縁部及び当
て板に沿った部分では, 雨水及び空気の侵入が容易であ るためにカソード反応が起こりやすく, 腐食速度が大き くなったものと考学られる10)。また, 同じモデル・タン クによる腐食モニタリング結果でも7)，梅雨期及び降雪 期（消雪のために散水を行う）の水が侵入しやすい時期 の腐食速度が増加して和り, 上述の推定を裏付けてい る。

角田ら ${ }^{11)}$ とよる型タンク (直径 $60 \mathrm{~m} \sim 80 \mathrm{~m}$ ) の試 験では, 顕著な腐食はタンク外周部に多く, その要因と して水分の多少よりむしろ酸素（空気）の供給を挙げて いる。本報のモデル・タンクは直径 $2 \mathrm{~m}$ であり, タン ク底板全面が彼らのいら外周部に含まれてしまらが, 雨 仕舞いがないことや当て板コーナー部の存在により, 短 期間で明膫な腐食速度の差を生じ, 腐食量と空気の侵入 との相関がはっきりしたと考兄られる。

さらに通常の土壤腐食に㧤いては, 通気差に上るマク ロセルが形成され, 空気 (酸素) 供給量少ない部分がア ノードとなり腐食速度が増加することが述べられてい る12)。しかしながら, 本報のモデル・タンクではアスフ ァルト・サンドの比抵抗が十分に大きく, 広範なマクロ セル電流が遮断され, 空気供給量の多い部分だけで腐食 が進行したものであろう。

以上のことから，アスファルト・サンド上に設置され たタンク底板の 腐食では, 底板/アスファルト・サンド 界面への水及び空気の供給速度が腐食速度に支配的影響 を与えることがわかった。

\section{5. 結言}

アスファルト・サンド層と接する鋼板の腐食につい て，モデル・タンク及び実験室試験により交流インピー ダンス特性と腐食状況との対応を調べた。その結果, イ ンピーダンス特性はアスファルト・サンド層をかなり小 さな抵抗 $R_{\mathrm{f}}$ と容量 $C_{\mathrm{f}}$ を持つ塗膜と考兄る等価回路に より説明され，この層の劣化は $R_{\mathrm{f}}$ の低下と対応してい ること, 測定される腐食反応抵抗 $R_{\mathrm{cor}}$ が底板の腐食速 度に対応すること，アスファルト・サンド/タンク底板 界面への雨水及び空気の侵入が腐食速度を増加させるこ とが明らかとなった。さらにこれらの結果は, 既に一部 を報告し，また継続中である交流法腐食モニターによる 測定に，実験的根拠を与えた。

(Received August 1, 1986)

\section{文献}

1）自治省消防庁：“屋外貯蔵 タンクの腐食事例の 調查及び検討報告書”, 危険物保安技術協会, (1982).

2) 亀井浅道：ケミカル・エンジニアリング，25, 9 (1980). 
3) 重野隼太, 岡本勝群: 石油と石油化学, 16, 46 (1972).

4）“石油タンクの防食及び腐食管理指針”, 日本高 圧力技術協会, (1981).

5）春山志郎, 水流 徹, 阿南正治：防食技術, 27, 449 (1978).

6) 水流 徹, 春山志郎：防食技術, 27, 573 (1978), S. Haruyama \& T. Tsuru: "Electrochemical Corrosion Testing ASTM STP727”, Eds. F. Mansfeld \& U. Bertocci, ASTM p. 167 (1981).

7) T. Tsuru, S. Sudoh \& S. Haruyama: "Computer Aided Acquisition and Analysis of Corrosion Data", Eds. M. Y. Kendig \& U. Bertocci, The Electrochemical Society, p. 45, 1985,
S. Sudoh, T. Tsuru \& S. Haruyama: Proc. 4th Asian-Pacific Corros. Cont. Conf., Vol. 2, p. 1325 (1985).

8) 水流 徹, 須藤 皓, 春山志郎: 電気化学, 51 , 159 (1983).

9) 浅利満頼, 水流 徹, 春山志郎: 第 32 回腐食 防食討論会予稿集 (1985, 8 札幌)，B-204(1985), M. Asari, T. Tsuru \& S. Haruyama: J. Electrochem. Soc., Submitted.

10）亀井浅道：防食技術，33，654 (1984).

11）角田知已, 秋葉徹郎, 水流 徹, 春山志郎: 腐 食防食 '86, B-106 (1986).

12）伊藤伍郎：“腐食科学と防食技術”, コロナ社, p. 352 (1969). 